Metabolic Issues of Clinical Nutrition 


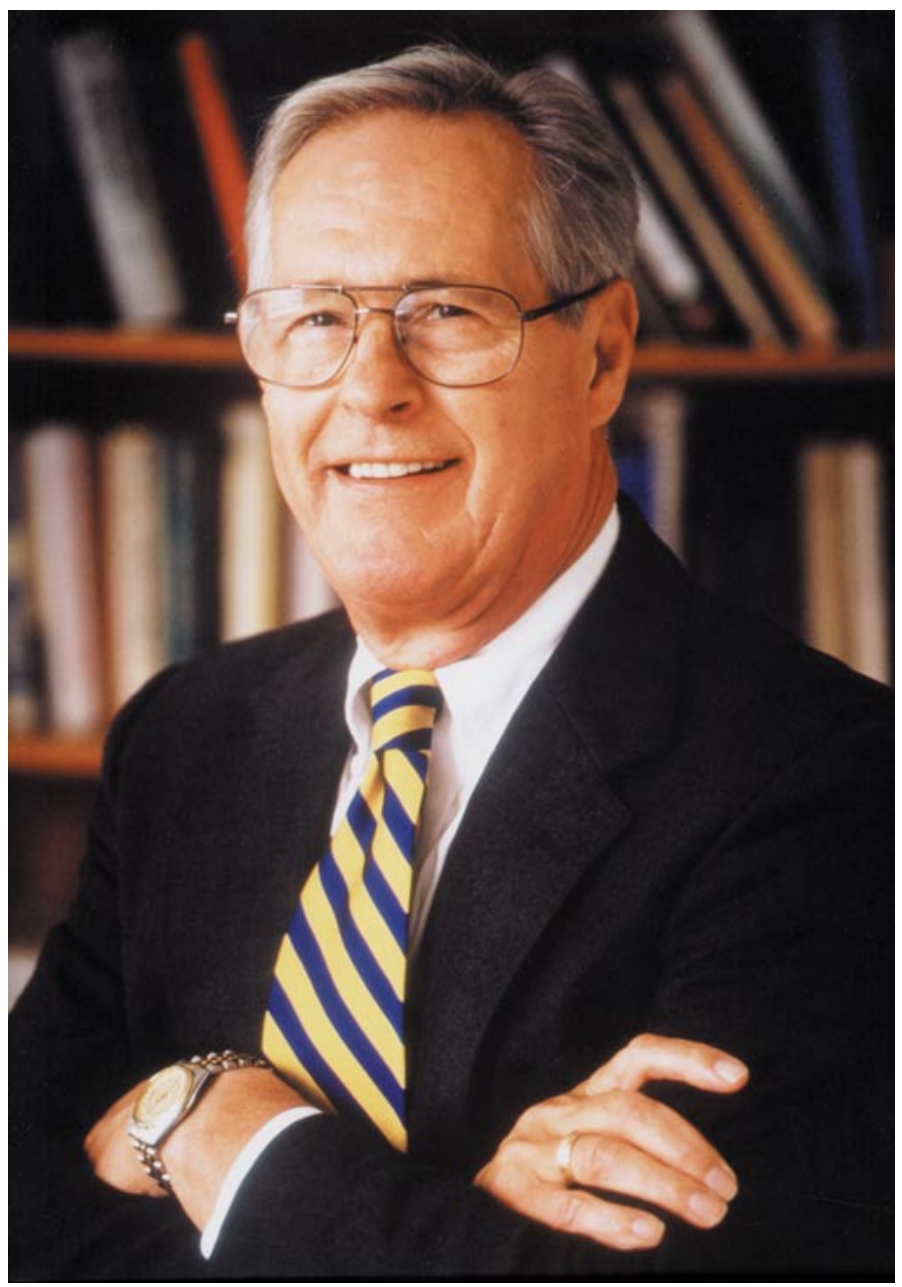

This book is dedicated to the late Vernon Young, with all our gratitude for his great contribution to the development of clinical nutrition. 
Nestlé Nutrition Workshop Series

Clinical \& Performance Program, Vol. 9

\section{Metabolic Issues of Clinical Nutrition}

Editors

Simon P. Allison, Nottingham, UK

Vay Liang W. Go, Los Angeles, Calif., USA 


\section{Nestec Ltd., 55 Avenue Nestlé, CH-1800 Vevey (Switzerland) S. Karger AG, P.O. Box, CH-4009 Basel (Switzerland) www.karger.com}

(C) 2004 Nestec Ltd., Vevey (Switzerland) and S. Karger AG, Basel (Switzerland). All rights reserved. This book is protected by copyright. No part of it may be reproduced, stored in a retrieval system, or transmitted, in any form or by any means, electronic, mechanical, photocopying, or recording, or otherwise, without the written permission of the publisher.

Printed in Switzerland on acid-free paper by Reinhardt Druck, Basel

ISBN 3-8055-7756-7

ISSN 1422-7584

\section{Library of Congress Cataloging-in-Publication Data}

Metabolic issues of clinical nutrition / editors, Simon P. Allison, Vay Liang W. Go.

p. ; cm. - (Nestlé Nutrition workshop series, Clinical \& performance program, ISSN $1422-7584$; v. 9)

Includes bibliographical references and index.

ISBN 3-8055-7756-7 (hard cover)

1. Diet therapy-Congresses. 2. Metabolism-Congresses. 3.

Metabolism-Disorders- Congresses. 4. Non-insulin-dependent diabetes-Congresses. I. Allison, Simon P. II. Go, Vay Liang W. III. Nestlé Nutrition workshop series. Clinical \& performance programme ; v. 9.

[DNLM: 1. Metabolism-Congresses. 2. Nutrition-Congresses. 3. Metabolic

Diseases-Congresses. 4. Nutrition Disorders-Congresses. QU 145 M587 2004]

RM214.M484 2004

$615.8^{\prime} 54-\mathrm{dc} 22$

2004052835

KARGER

Basel · Freiburg · Paris · London · New York .

Bangalore $\cdot$ Bangkok $\cdot$ Singapore $\cdot$ Tokyo $\cdot$ Sydney

The material contained in this volume was submitted as previously unpublished material, except in the instances in which credit has been given to the source from which some of the illustrative material was derived.

Great care has been taken to maintain the accuracy of the information contained in the volume. However, neither Nestec Ltd. nor S. Karger AG can be held responsible for errors or for any consequences arising from the use of the information contained herein. 


\section{Contents}

VII Preface

IX Foreword

XI Contributors

1 Under- and Overnutrition: A Global Perspective James, W.P.T.; Leach, R.; Rigby, N. (London)

19 Environmental Influences on Diseases in Later Life Tappy, L.; Seematter, G.; Martin, J.-L. (Lausanne)

37 Insulin Sensitivity: Normal and Abnormal Basu, A. (Rochester, Minn.)

53 Insulin Resistance in Catabolic Diseases Allison, S.P.; Martinez-Riquelme, A. (Nottingham)

69 Mechanisms of Insulin-Induced Alterations in Metabolism during Critical Illness

Mesotten, D.; Van den Berghe, G. (Leuven)

77 The Metabolic Syndrome as a Clinical Problem Kopelman, P. (London)

93 The Effect of Exercise and Diet on Glucose Intolerance and Substrate Utilization?

Astrup, A. (Copenhagen)

Presentation and discussion by Allison, S. (Nottingham)

111 Muscle Mass and Protein Metabolism

Biolo, G. (Trieste); De Cicco, M. (Aviano) 
125 Fatty Acid Isomers in Lipid Metabolism

Sébédio, J.L.; Bretillon, L.; Chardigny, J.M.; Berdeaux, O. (Dijon)

141 Pathogenic Role of Inflammatory Cytokines in Obesity: From Insulin Resistance to Diabetes mellitus Marette, A. (Ste-Foy)

155 Diet Modifications to Control Hypertension: The Multifactorial Approach Rock, C.L. (San Diego, Calif.)

169 The Role of Minerals and Trace Elements in Relation to Long-Term Health and Chronic Disease Shenkin, A. (Liverpool)

187 Fluid and Electrolytes in the Clinical Setting Lobo, D.N. (Nottingham)

205 Water and Sodium Balance: A Nutritional Goal Sitges-Serra, A. (Barcelona)

227 Neuro-Hormonal Integration of Metabolism: Challenges and Opportunities in the Postgenomic Era Go, V.L.W.; Wang, Y.; Yang, H.; Lee, W.-N.P. (Los Angeles, Calif.)

243 Nutrition and Genomics German, B. (Lausanne/Davis, Calif.); Young, V.R. (Cambridge, Mass.) Presentation and discussion by German, B. (Lausanne/Davis, Calif.)

265 Subject Index 


\section{Preface}

In devising this program with our Nestlé colleagues we have attempted not only to review some of the new developments and pressing problems in clinical nutrition and metabolism, but also to develop some unifying themes running across the nutritional spectrum, from undernutrition to obesity, and from starvation and weight loss to acute medical and surgical illness. Recurring issues such as insulin resistance, changes in intermediary metabolism, fluid and electrolyte physiology, and genetic and non-genetic inheritance are highlighted, as is the biological paradox linking maternal undernutrition to the development of obesity, diabetes and cardiovascular disease in later life, a phenomenon that may persist through several subsequent generations by mechanisms still poorly understood. This creates problems not only for the developed world, but also for nations that have experienced the combination of undernutrition (present or previous) and rapid urbanization and its associated changes in lifestyle. Asian countries, including India and China, follow in the wake of Europe and the USA, with rapid rises in the prevalence of obesity and type- 2 diabetes that are now reaching epidemic proportions. The implications for current and future health policy and costs are enormous. A nihilistic or ostrich policy is inappropriate and a recipe for disaster.

It seems extraordinary to us that while these medical problems of over- and undernutrition are now surpassing infectious diseases in terms of prevalence, most doctors are largely ignorant of nutritional medicine and the undergraduate medical curriculum pays it scant attention.

Practical issues of policy and management are reviewed. Thailand has made remarkable strides to reduce childhood malnutrition by taking direct local action even before there is any improvement in poverty levels. This calls into question the concept that reduction in poverty, though highly desirable, is a necessary prerequisite for reducing malnutrition. This Workshop also addresses some of the ways that diet and lifestyle can be effectively modified to counteract obesity. Without national political and educational programs, however, the efforts of health care professionals will be insufficient. This Workshop underscores the diversity of topics, ideas, and opinions expressed during the 3 enjoyable days in Bangkok, and will enhance current and future 
Preface

research and public health and policy issues as we continue to gain new knowledge in the metabolic basis for the practice of clinical nutrition.

It has been a privilege to chair and participate in this Workshop of distinguished colleagues, to whom we express our thanks for their lively and interesting contributions. We also wish to express our thanks to our colleagues at Nestlé for their splendid organization and support.

Simon P. Allison and Vay Liang W. Go 


\section{Foreword}

For this 9th Nestlé Nutrition Workshop of the Clinical and Performance Program, which took place in November 2003 in Bangkok, the topic 'Metabolic Issues of Clinical Nutrition' was chosen.

In the field of clinical nutrition we are aware of factors which may play a role in the assessment of the patients' needs. Malnutrition and overweight, insulin resistance, blood pressure, the fluid and electrolyte state, interactions between diet, the individual's genetic background, hormonal and immunological factors as well as the degree of possible physical activity may be taken into individual consideration.

I would like to thank the chairmen, Prof. Simon Allison and Prof. Vay Liang Go, who are well-known experts in the metabolic factors of clinical nutrition, for putting the program together and inviting as speakers the opinion leaders in different fields in order to discuss the interrelationships between the factors mentioned above. Physicians invited from 12 countries contributed to the discussions that are published in this book. Mrs. Vipapan Panitantum and her team from Nestlé Thailand provided all logistical support, so that participants gained an appreciation of Thai hospitality. Dr. Philippe Steenhout from Nestlé's Nutrition Strategic Business Division in Lausanne, Switzerland, was responsible for the scientific coordination. His cooperation with the chairpersons was essential for the success of this workshop.

Prof. Wolf Endres, $M D$

Vice-President

Nestec Ltd., Lausanne, Switzerland 


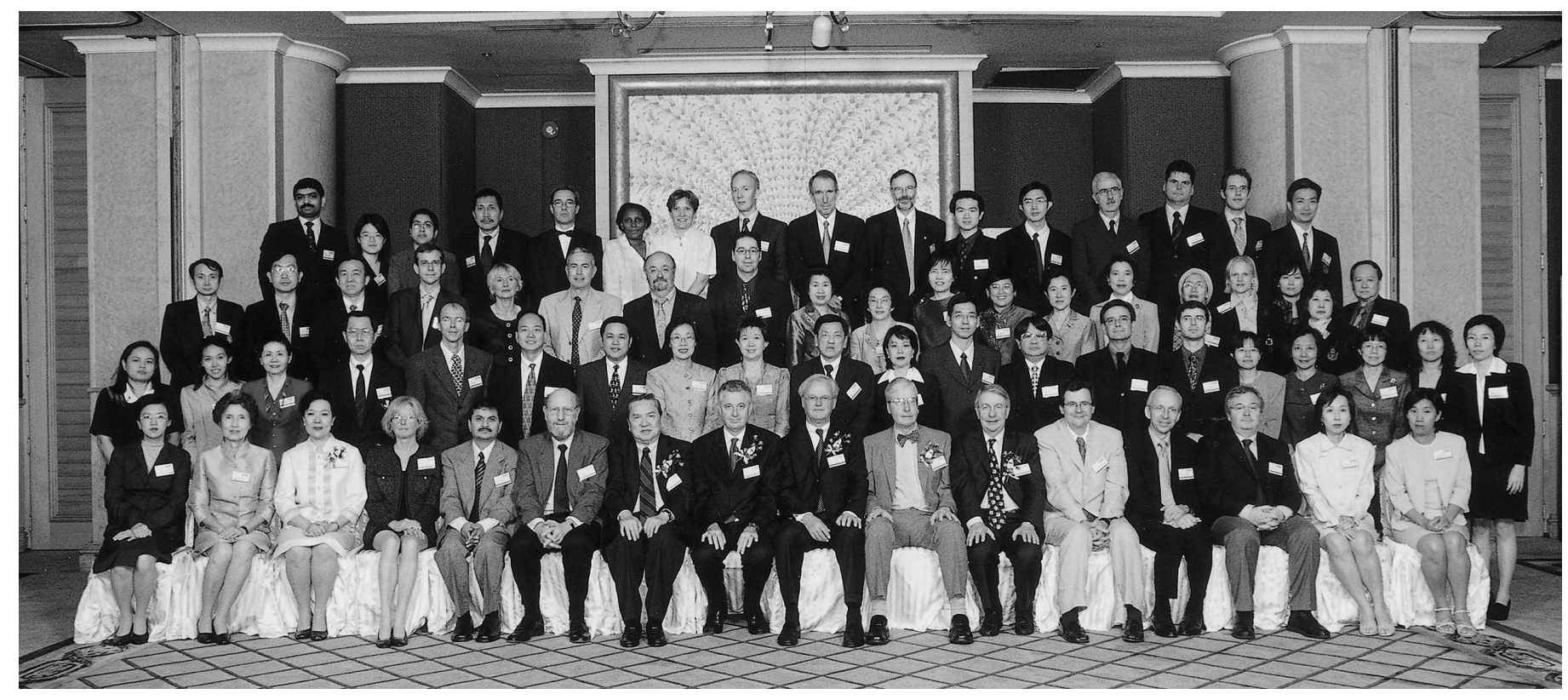

9th Nestlé Nutrition Workshop

Clinical \& Performance Program

Bangkok, Thailand, November 16-20, 2003 


\section{Contributors}

\section{Chairpersons and Speakers}

\section{Prof. Simon Allison}

Queen's Medical Centre

Nottingham NG7 2UH, UK

Tel. +44 1159249924

Fax +441159194427

E-Mail simon.allison@mail.

qmcuh-tr.trent.nhs.uk

\section{Dr. Ananda Basu}

Mayo Clinic

200 First Street SW

Rochester, MN 55905, USA

Tel. +1 5072843754

Fax + 15072554828

E-Mail basu.ananda@mayo.edu

\section{Prof. Gianni Biolo}

Clinica Medica, Ospedale di

Cattinara

Strada di Fiume, 447

IT-34149 Trieste, Italy

Tel. + 39403994532

Fax +39403994593

E-Mail biolo@units.it

\section{Prof. Bruce German}

Direction Nestlé Research Center

Vers-chez-les-Blanc

CH-1000 Lausanne 26

Switzerland

Tel. +41217858341

Fax +41217858308

E-Mail bruce.german@rdls.nestle.com

\section{Prof. Vay Liang W. Go}

David Geffen School of Medicine at UCLA

900 Veteran Avenue, Room 12-217

Los Angeles, CA 90095-1742, USA

Tel. +1 3107947848

Fax + 13108245990

E-Mail vlwgo@ucla.edu

\section{Prof. W. Philip T. James}

International Obesity Task Force

Division of Endocrinology and

Metabolism

231 N. Gower Street

London NW1 2NS, UK

Tel. +44207691 1900

Fax +442073876033

E-Mail jeanhjames@aol.com

\section{Prof. Peter G. Kopelman}

Barts and The London Queen Mary's School of Medicine and Dentistry

Medical School Building

London E1 2AD, UK

Tel. +44207377 7602

Fax +44207377 7621

E-Mail p.g.kopelman@qmul.ac.uk

\section{Mr. Dileep N. Lobo}

University Hospital, Queen's Medical Centre

Section of Surgery

E Floor, West Block 
Nottingham NG7 2UH, UK

Tel. +441159249924

Fax +44 1159709428

E-Mail

dileep.lobo@nottingham.ac.uk

\section{Dr. André Marette}

CHUL Research Center - CRML

Laval University Hospital Research

Center

2705 Laurier

Ste-Foy, Québec G1V 4G2

Canada

Tel. +1 4186564141 (7549)

Fax +1 4186542176

E-Mail

andre.marette@crchul.ulaval.ca

\section{Dr. Dieter Mesotten}

Intensive Care Medicine

University Hospital Gasthuisberg

BE-3000 Leuven, Belgium

Tel. + 3216344021

Fax + 3216344015

E-Mail

dieter.mesotten@med.kuleuven.ac.be

\section{Dr. Cheryl L. Rock}

University of California, San Diego

Department of Family and Preventive Medicine

9500 Gilman Drive, Dept. 0901

La Jolla, CA 92093-0901, USA

Tel. +1 8588221126

Fax +1 8588221497

E-Mail clrock@ucsd.edu

\author{
Dr. Jean-Louis Sébédio
}

INRA - Unité de Nutrition Lipidique

17 rue Sully

FR - 21065 Dijon Cédex

France

Tel. +33 380693123

Fax + 33380693223

E-Mail sebedio@dijon.inra.fr

\section{Prof. Alan Shenkin}

University Department of Clinical Chemistry

4th Floor Duncan Building

Daulby Street

Liverpool L69 3GA, UK

Tel. +44 1517064232

Fax +441517065813

E-Mail shenkin@liverpool.ac.uk

\section{Prof. Antonio Sitges-Serra}

Hospital del Mar

Department of Surgery

P. Marítim, 25-29

ES-08003 Barcelona, Spain

Tel. + 34932483208

Fax +34 932483406

E-Mail asitges@imas.imim.es

\section{Prof. Luc Tappy}

Université de Lausanne

Faculté de Médecine

Institut de physiologie

Rue de Bugnon 7

CH-1005 Lausanne

Switzerland

Tel. +41216925541

Fax +41216925595

E-Mail luc.tappy@iphysiol.unil.ch

\section{Moderators}

\section{Prof. Pongamorn Bunnag}

Mahidol University

Department of Medicine Ramathibodi

Hospital

Endrocrine and Metabolism Unit

Bangkok 10400, Thailand

Tel. +66 22011647

Fax +662201 1715

E-Mail rapbn@mahidol.ac.th

\section{Prof. Kallaya Kijboonchoo}

Mahidol University, Salaya Campus

Institute of Nutrition

Physiological Nutrition Division

Nakhon Pathom 73170, Thailand

Tel. +66 2800 2380/ext. 112

Fax +6624419344

E-Mail grkkb@mahidol.ac.th 


\section{Dr. Nopawan Kittivat}

Bumrungrad Hospital

Department of Medicine

Bangkok 10110, Thailand

Tel. +66 26671346

Fax +66 26671347

E-Mail info@bumrungrad.com

\section{Prof. Surat Komindr}

Mahidol University

Faculty of Medicine

Ramathibodi Hospital

Department of Medicine

Nutrition and Biochemical Medicine

Division

Bangkok 10400, Thailand

Tel. +6622011631

Fax +6622011611

E-Mail rasco@mahidol.ac.th or

Komi@ksc.th.com

\section{Prof. Vorasuk Shotelersuk}

Chulalongkorn University

Department of Pediatrics
Faculty of Medicine

Medical Genetics and Metabolism

Bangkok 10330, Thailand

Tel. +6622564989

Fax +6622564911

E-Mailvorasuk.s@chula.ac.th

\section{Prof. Vasant Sumethkul}

Mahidol University

Department of Medicine

Ramathibodi Hospital

Renal Unit

Bangkok 10400, Thailand

Tel. +66 22011400

Fax +66 22462123

E-Mail ravsm@mahidol.ac.th

\section{Prof. Emorn Wasantwisut}

Mahidol University

Institution of Nutrition

Salaya, Phutthamonthon 4

Nakhon Pathom 73170, Thailand

Tel. +66 2800 2380/ext. 305

Fax +6624419344

E-Mailnumdk@mahidol.ac.th

\section{Invited attendees}

Dr. Dieter Mesotten / Belgium

Prof. Olli Simell / Finland

Ms. Michele Boncompain / France

Prof. Jacques Cosnes / France

Dr. Dominique Lescut / France

Dr. Laurent Petit / France

Dr. Siti Setiati / Indonesia

Dr. Untung Sudomo / Indonesia

Dr. Eva Njenga / Kenya

Ms. Mary Easaw / Malaysia

Dr. Gerry Tan / Philippines

Prof. Alberto Mijan-be-la-Torre /

Spain

Dr. Jordi Salas Salvado / Spain

Prof. Jongjit Angkatavanich /

Thailand

Dr. Apussanee Boonyavarakul /

Thailand

Dr. Phairuch Chaiyakul / Thailand

Dr. Nopaorn Chantrarat /

Thailand
Dr. Kaweesak Cheittawatanawat /

Thailand

Dr. Amnard Chitvaranun / Thailand

Prof. Nalinee Chongviriyapan / Thailand

Khun Mayuree Dithmetharoj / Thailand

Khun Jurerat Horkiet / Thailand

Prof. Vongsvat Kosulwat /

Thailand

Dr. Wantanee Kriengsinyos /

Thailand

Dr. Pawadee Kuncharanussorn /

Thailand

Prof. Ladda Mo-Suwan /

Thailand

Prof. Thanyadej Nimmanwudipong / Thailand

Dr. Anadi Nitithamyong / Thailand

Prof. Charnchai Panthongviriyakul / Thailand 
Prof. Worapat Picarkitjaganwattana / Thailand

Dr. Veeradej Pisprasert / Thailand

Dr. Orawan Poochaiwattananon / Thailand

Prof. Puttisak Puttawibul / Thailand

Prof. Chulaporn Roongpisothipong / Thailand

Khun Trerat Roongrojchaiyaporn / Thailand

Prof. Prapaisri Sirichakwal / Thailand

Prof. Sriwattana Songjitsomboon / Thailand

Prof. Umaporn Suthutvoravut / Thailand

Dr. Ruangvith Tantibhaedhyangkul / Thailand

Prof. Dr. Prasong Tienboon / Thailand

Dr. Daruneewan Warodomwichit / Thailand

\section{Nestlé participants}

Dr. Franck Arnaud-Battandier / France Dr. Mike Possner / Germany

Ms. Jaen Ang / Malaysia

Mr. Eric Deluna / Philippines

Prof. Wolf Endres / Switzerland

Mrs. Catherine Mace / Switzerland

Dr. Eduardo Schiffrin / Switzerland

Dr. Philippe Steenhout / Switzerland

Ms. Piyanat Bunnitigon / Thailand

Mr. Phairoj Nirunpornbuddha /

Thailand

Mrs. Vipapan Panitantum / Thailand Ms. Sopita Siriratana / Thailand Mrs. Heidi Storm / USA 